\title{
LAW REFORM IN NIGERIA: A HISTORICAL PERSPECTIVE ${ }^{1}$
}

\author{
Tonye Clinton Jaja ${ }^{1 \bowtie}$, Emmanuel O. Anyaegbunam \\ ${ }^{1}$ Senior Research Fellow, National Institute for Legislative and Democratic Studies \\ (NILDS), Abuja, Nigeria. \\ ${ }^{2}$ Director - African Centre for Parliamentary \& Constitutional Studies \\ $\bowtie$ tonyeclintonjaja@yahoo.com
}

\section{CITED AS}

Jaja, T.C., \& Anyaegbunam, E.O (2020). Law Reform in Nigeria: A Historical Perspective. Journal of Law and Legal Reform, 1(3), 437-444. DOI: https://doi.org/10.15294/jllr.vli3.36702

\begin{abstract}
The paper is intended to analyze and describe the legal reform in Nigeria from historical perspective. This Country, Nigeria, has a long and complicated history of its legal system. Law and legislation in Nigeria is affected by some internal and external factors, such as culture, and globalization. this paper seeks to appraise the history of law reform in Nigeria with comparative analysis of other jurisdictions, evaluate the current state of legislation in Nigeria, highlight the challenges and obstacles that have imperiled law reform in Nigeria and articulate relevant remedial measures as the solution for these age-long problems.
\end{abstract}

Keyword: Law Reform; Nigeria; Historical Perspective; Comparative

1 Adapted from the text a Paper delivered at the Training of Nigerian Law Reform Commission Lawyers on July 20 - 21, 2017 at the Commission's Office, Abuja 


\title{
TABLE OF CONTENTS
}

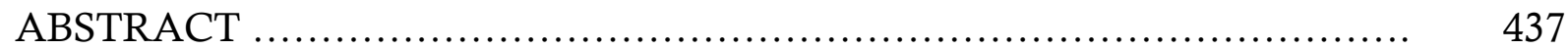

TABLE OF CONTENTS ............................................... 438

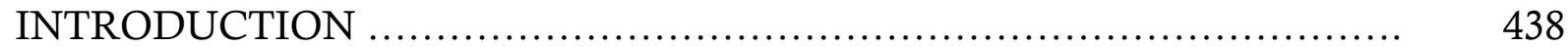

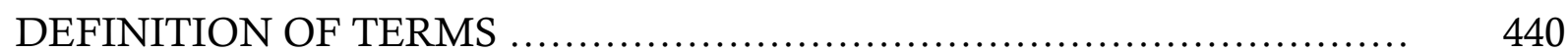

I. CODIFICATION ................................................. 440

II. CONSOLIDATION OF LAWS ..................................... 441

III. LAW REVIEW .................................................. 441

LAW REFORM IN NIGERIA ........................................ 442

I. LAW REFORM ...................................................... 442

II. LAW REVISION ..................................................... 442

CONCLUSION ........................................................ 443

REFERENCES ............................................................. 444

\section{INTRODUCTION}

Change and improvement cannot be affected without legislation. Legislation will be much improved if it has a law reform background or input which brings with it a high level of thoroughness. Without this, some laws may begin to manifest defects and become liable to amendment soon after coming into force.

\author{
Professor C. O. Okonkwo, SAN \\ July 16 - 17, 2012 in Abuja
}

Law is an inevitable instrument that enables a State to carry out its activities and its desired ends. It is the body of laws in its totality that characterise the State as the supreme organ or authority under whose power and influence every person or organ within its sovereign jurisdiction are made subject to. Hence, supremacy of the Constitution and rule of law become the compelling dictum of virtually all democracies and even undemocratic entities.

In essence, law regulates and controls the affairs of man within a given society. As aptly reasoned by Kefas Magaji and P. C. Okorie: 
Law refers to a system of rules which a particular country or community recognizes as regulating the actions of its members and which it may enforce by the imposition of penalties. It is a system of rules that govern a society with the intention of maintaining social order, upholding justice and peaceful co-existence (Magji \& Okorie 2017).

B. Nwabueze lend support to the above stance in his combination of law as an attribute of state power in these words:

In more succinct language, the state denotes power and force exercised "in the name of law"; it connotes a legal order, a body of laws that regulates, conditions and qualifies the exercise of power backed by force within a given community (Nwabueze 2010).

It follows that the 1999 Constitution of the Federal Republic of Nigeria was in sync with the above cited postulates when it provides vide section 4 (2) that:

(2) The National Assembly shall have power to make laws for the peace, order and good government of the Federation or any part thereof with respect to any matter included in the Exclusive Legislative List set out in Part I of the Second Schedule to this Constitution.

Every society or human community grows and in the course of that, the laws of the land follow the dynamic changes and attendant innovation and update. The long title to the Nigerian Law Reform Commission Act, Cap. N118, Laws of the Federation of Nigeria, 2004 captured this universal reality as:

An Act to set up a Law Reform Commission for Nigeria to undertake the progressive development and reform of substantive and procedural law applicable in Nigeria by way of codification, elimination of anomalous or obsolete laws and general simplification of the law in accordance with general directions issued by the Government, from time to time and for matters connected therewith.

It is in the context of this core mandate of the Law Reform Commission that this paper seeks to appraise the history of law reform in Nigeria with comparative analysis 
of other jurisdictions, evaluate the current state of legislation in Nigeria, highlight the challenges and obstacles that have imperiled law reform in Nigeria and articulate relevant remedial measures as the solution for these age-long problems.

\section{DEFINITION OF TERMS}

This subject matter calls for definition, clarification and highlight of key terms which are as follows:

\section{CODIFICATION}

Black's Law Dictionary has it as:

The process of compiling, arranging, and systematizing the laws of a given jurisdiction, or of a discrete branch of the law, into an ordered code. 2. The code that results from this process (Gardner 2016).

Despite the above definition, codification of law is a term that is open to many qualification and description to many people. As was aptly remarked by M. Sayers:

Codification means different things to different people. At its simplest, it may be no more than the reduction to statutory rules of a relatively confined area of common law. If the area is small, the result may be a relatively simple set of statutory provisions. The Occupiers' Liability Act 1957 C3l (UK) is often regarded as a prime example. But for many codifications is a more ambitious, and inevitably less attainable dream. For them, it represents the desire to reduce the whole body of the law, or very large tracts of it, to a simple set of clearly expressed principles (Okonkwo 2012).

We must advert our minds to the Roman legacy through the Code of Justinian of 529AD, which codified all existing legislation from the time of Emperor Hadrian, 117 138AD. It was chosen as the baseline with modification necessary to "purge the errors and contradictions, to retrench whatever was obsolete or superfluous", retaining only such laws as were "wise and salutary and best adopted to the practice of the tribunals and the use of the people" (Nwabueze 2017). 
Codification entails a diligent derivation or taking out of all laws within a particular subject matter and condensing same into a single Act (Code) in order to attain predictability, simplicity and certainty within a legal regime. In this wise, the Criminal Code Act, Occupiers Liability Act of 1957 and the Company and Allied Matters Act, become readily available examples.

\section{CONSOLIDATION OF LAWS}

Consolidate means to combine, amalgate, assembly or unify into one mass or body. Therefore, it is the act of combining two or more separate laws on the same subject into a single statute. Consolidation goes further to restructure the words of a law with the view to make same shorter, clearer and more accessible.

It bears the same connotation with codification but differs in the sense that it advances into editing and restructuring of the words of the statutes for clearer and better usage. Law revision can be adjudged as consolidation of laws.

\section{LAW REVIEW}

This is a preliminary step in readiness for a law revision or law reform exercise. It involves a diligent comprehensive research and prudent analysis and assessment of the existing laws with the view of identifying areas of the laws that require reform or revision.

Law Review will entail holistic review and analysis of books, articles, journals and other materials by learned scholars. Thus, it will help to expose problems and shortcomings in the existing legislations and proffer lasting possible solutions.

If we planned and proactively executed, workshops and seminars by stakeholders and learned specialists in all fields of law will serve this purpose prior to a law reform or revision exercise. 


\section{LAW REFORM IN NIGERIA}

\section{LAW REFORM}

This involves a progressive improvement in the existing law in order to meet the changing needs of a society. It is simply means the dynamic attunement of the existing laws of a society in line with its growth and development. Law Reform also includes the introduction of entirely new legislations in a legal system as required by the technological and development trend of the society. As aptly affirmed by Wikipedia:

Law reform or Legal reform is the process of examining existing laws, and advocating and implementing changes in a legal system, usually with the aim of enhancing justice or efficiency.

Intimately related are law reform bodies or law commissions, which are organizations set up to facilitate law reform. Law reform bodies carry out research and recommend ways to simplify and modernize the law. Many law reform bodies are statutory corporations set up by governments, although they are usually independent from government control, providing intellectual Independence to actually reflect and report on how the law should progress.

Law reform activities can include preparation and presentation of cases in court in order to change the common law; lobbying of government officials in order to change legislation; and research or writing that helps to establish an empirical basis for other law reform activities.

It is pertinent to note, that law reform must be anchored by a legislation. Thus, involving a substantive legislative change.

\section{LAW REVISION}

The underlying purpose of a law revision, is to update the set of statues in force in a legal system at a particular date, usually within a period of ten years. Hence, its focus is to incorporate all amendments and adaptations made to the statutes since the last 
revision exercise and also eliminate all repealed, obsolete, spent and other unnecessary matters. H. M. Marshall's definition is instructive that:

The purpose of a statute law revision (in some countries described as a "reprint") is to prepare and provide for public use an up-to-date set of the statutes in force in a particular territory at a particular date, incorporating all amendments and adaptations made thereto since the previous Revision and eliminating therefrom all repealed, obsolete, spent and other unnecessary matters. This type of law revision must be distinguished from the process of law reform which involves the making of substantive legislative changes in the statute and other law of a territory with a view to its improvement and modernization.

Our position in Nigeria is that law revision is authorized and governed by specific statute through an ad-hoc committee under a Chairman of the Law Revision Committee. It is carried out within intervals of ten to fifteen years. In this wise, there 1948, 1958, 1990 and 2001 - for laws of the Federation of Nigeria 2004 and consequent revision of the 2004 in 2010.

The law requires the enactment of a specific legislation by the National Assembly to bring the new statutes into force. Law revision is not law reform because the law revision committee has no authority to reform laws. Where the law revision committee encounters a law reform subject, it should refer same to the National Assembly for appropriate enactment. The (Laws of the Federation of Nigeria) Act, 2007 which authenticated LFN 2004 served this saving measure for the 2004 exercise which had no force of law until the 2007 enactment.

\section{CONCLUSION}

This paper concludes that law reform in Nigeria has a long history and its own problems. Some changes and improvements of laws in Nigeria based on the special legislations, however, the legislation in fact does not reflect some people opinion. The underlying purposes of a law revision is to update the set of statues in force in a legal system at a certain date, usually within a period of ten years. Hence, its focus is to incorporate all amendments and adaptations made to the statutes since the last revision exercise and also eliminate all repealed, obsolete, spent and other unnecessary matters 


\section{REFERENCES}

Gardner, B.A. (2016). Black's Law Dictionary" (8 ${ }^{\text {th }}$ Ed). St Paul: West Publishing Co. MN 20004.

Magji, K., \& Okorie, P. C. (2017). Amendment of Legislation, Law Review and Law Reform, presented for Parliamentary Staff of ECOWAS Member States July 6, 2017, at ECOWAS Parliament, Abuja.

Nwabueze, B. (2010). Colonialism in Africa: Ancient and Modern Vol. 1. Ibadan: Gold Press Limited.

Nwabueze, B. (2017). Save Our Constitutional Democracy from Emasculation. Ibadan: John Archers Publishers Ltd.

Okonkwo, C.O. (2012). The Imperatives of Law Reform in the Law-Making Process. Unpublished Paper, Abuja, July 16 - 17, 2012.

Wikipedia (2010). Law Reform, retrieved from

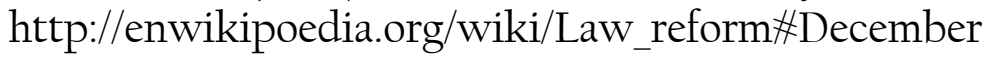

